\title{
Seroprevalence of human T-cell lymphotropic virus type I among pregnant women in Accra, Ghana
}

\begin{abstract}
Correspondence
Henry B. Armah

harmah@msm.edu
\end{abstract}

Received 20 November 2005

Accepted 4 February 2006

\author{
Henry B. Armah, ${ }^{1,2}$ Edwin G. Narter-Olaga, ${ }^{2}$ Andrew A. Adjei, ${ }^{2}$ \\ Kofi Asomaning, ${ }^{3}$ Richard K. Gyasi ${ }^{2}$ and Yao Tettey ${ }^{2}$ \\ ${ }^{1}$ Department of Microbiology, Biochemistry \& Immunology, Morehouse School of Medicine, \\ Hugh Gloster Building (BMSB) Room 350, 720 Westview Drive SW, Atlanta, \\ GA 30310-1495, USA \\ ${ }^{2}$ Department of Pathology, University of Ghana Medical School, Korle-Bu, Accra, Ghana \\ ${ }^{3}$ Department of Environmental Health, Harvard School of Public Health, Boston, MA, USA
}

\section{INTRODUCTION}

Human T-cell lymphotropic virus type I (HTLV-I) is known to be the pathogenic agent of adult T-cell leukaemia/lymphoma (ATLL) (Poiesz et al., 1980; Yoshida et al., 1982) and HTLV-I-associated myelopathy/tropical spastic paraparesis (Gessain et al., 1985; Osame et al., 1987). ATLL develops after a long incubation period, with an estimated lifetime risk of approximately 3-8\% in individuals infected before the age of 20 years (Cleghorn et al., 1995). As the prognosis for patients with ATLL is extremely poor, with median survival after diagnosis of $<6$ months (Takatsuki et al., 1996), the prevention of mother-to-child transmission of HTLV-I is of the utmost importance. HTLV-I is not ubiquitous, but is endemic in some geographical areas and among some ethnic groups. Population-based studies have reported the prevalence of antibody to HTLV-I to range from 3-6\%

Abbreviations: ATLL, adult T-cell leukaemia/lymphoma; HIV, human immunodeficiency virus; HTLV-I, human T-cell lymphotropic virus type I; PAT, particle agglutination test; WB, Western blotting. in Jamaica, Trinidad and the Caribbean islands to $23 \cdot 2 \%$ in Nagasaki Prefecture in south-western Japan (Blattner et al., 1990; Murphy et al., 1991; Kishihara et al., 2001). High HTLV-I seroprevalence rates $(>2 \%$ in the adult population) have been described in southern Japan, sub-Saharan Africa, the Caribbean Basin, parts of South America and some areas of Melanesia and the Middle East, where 15-20 million people are infected with this virus (Kazanji \& Gessain, 2003). In every endemic population, there is an increase in HTLV-I seroprevalence with age, especially among women, reaching $40 \%$ in women $>50$ years of age (Kazanji \& Gessain, 2003).

HTLV-I is transmitted via infected lymphocytes by three main routes. Mother-to-child transmission, mainly due to ingestion of breast milk during breastfeeding, has been reported to be the predominant route (Tsuji et al., 1990). The rates of HTLV-I transmission from mother to child are $2.7 \%$ in formula-fed infants, $5 \%$ after 3 months of breastfeeding and up to $39 \%$ with prolonged breastfeeding 
(Tsuji et al., 1990; Hino et al., 1996; Takezaki et al., 1997; Wiktor et al., 1997). Antenatal screening for HTLV-I and the recommendation for formula feeding of infants of HTLVseropositive mothers have been carried out in the Nagasaki prefecture of Japan since 1987 (Hirata et al., 1992; Wiktor et al., 1997) and have been proposed in Europe (Nightingale et al., 1993; Weber \& Taylor, 1996; Hale et al., 1997; Otigbah et al., 1997; Taylor et al., 2005) and Jamaica (Hanchard, 1996). Sexual transmission, mainly from men to women, is the second most frequent route (Kajiyama et al., 1986). The man-to-woman transmission rate of married couples was $60 \%$ in 10 years, in contrast to a woman-to-man transmission rate of $0 \cdot 4 \%$ in 10 years (Kajiyama et al., 1986). The third most prevalent route is blood transfusion, which includes HTLV-I-positive cellular components (Okochi et al., 1984; Manns et al., 1992). The importance of this route has decreased since the introduction of screening of blood products for antibodies to HTLV-I in Japan in 1987 (Inaba et al., 1999) and subsequently in other countries (USA, UK, Canada, France, French West Indies, Portugal, Sweden, The Netherlands, Denmark and Finland) (Ades et al., 2000).

In Ghana, studies of HTLV-I seroprevalence in pregnant women have not been done previously. However, recently we reported HTLV-I seroprevalence rates of $4 \cdot 2$ and $11 \cdot 29 \%$ among blood donors and human immunodeficiency virus (HIV)/AIDS patients in Ghana, respectively (Adjei et al., 2003a, b). Two earlier studies among blood donors presenting to blood banks in the late 1990s in Ghana reported an HTLV-I seroprevalence of 0.5-0.7\% (Sarkodie et al., 2001; Ampofo et al., 2002). In a much earlier related study, Lal et al. (1994) reported the seroprevalence of HTLV-I among urban and rural dwellers in southern Ghana to be $1-2 \%$. Currently in Ghana, neither blood donors nor pregnant women are screened routinely for HTLV-I antibodies. In view of the national public health policy in Ghana since 1990 encouraging prolonged breastfeeding (exclusive breastfeeding for the first 4-6 months of life and then breastfeeding supplemented with other feeds up to 2 years of age; Ministry of Health, 1990) and the increased risk of HTLV transmission after prolonged breastfeeding, it is necessary to determine the prevalence of antibodies to HTLV-I among pregnant Ghanaian women. The present study was conducted to determine this and to assess the implications for both antenatal and blood-donor screening.

\section{METHODS}

Subjects. All of the 960 pregnant women who attended the prenatal/antenatal care unit of the 37 Military Hospital, Accra, Ghana, between January and December 2003 were studied. The excess sera from blood samples drawn from these 960 pregnant women for their routine antenatal (syphilis, $\mathrm{ABO}$ and Rhesus) testing, with all identifiers removed except for age, were assayed for antibodies to HTLV-I. The 37 Military Hospital is a 600-bed national tertiary referral hospital of the Armed Forces of Ghana and serves Ghanaian military personnel and their families or dependants, other military personnel on peacekeeping missions in the West African subregion and part of the population of the city of Accra. Accra, the capital city of Ghana, is a rapidly expanding city with a population of approximately 3 million. All HTLV-I-positive study subjects and their obstetricians were informed of the test result and counselled to bottle-feed their infants. The study was reviewed and approved by the Ethical and Protocol Review Committee of the University of Ghana Medical School, Accra, Ghana.

Specimen collection and serological tests. Venous blood samples were taken and sera were separated and kept frozen at $-20^{\circ} \mathrm{C}$ before being sent to our laboratory for testing. Fully informed consent was obtained from each study subject. When study subjects were younger than 18 years, informed consent was obtained from their parents. Samples were anonymous for the patient's name and hospital number, but data on age were retained. All of the sera were screened in duplicate for antibodies to HTLV-I/II by a gelatin particle agglutination test (PAT) (Serodia HTLV-I kit; Fujirebio) in accordance with the manufacturer's instructions. All samples that were repeatedly positive by PAT were confirmed by Western blotting (WB) (HTLV Blot 2.4 kit; Gene Labs Diagnostics). WB results were interpreted according to the manufacturer's instructions as follows: (i) HTLV-I positive, reactivity to GAG p19 (with or without p24) and two ENV (GD21 and rgp46I); (ii) HTLV-II positive, reactivity to GAG p24 (with or without p19) and two ENV (GD21 and rgp46II); (iii) HTLV positive, reactivity to GAG p19 and p24 and ENV GD21; (iv) indeterminate, reactivity to HTLV-specific bands detected but does not meet the criteria for HTLV-I, HTLV-II or HTLV seropositivity; and (v) HTLV negative, no reactivity to HTLV-specific bands.

Statistical analysis. The Statistical Analysis System version 9.1 (SAS Institute) was used to complete all data analyses. We divided the pregnant women into five categories of age: $\leqslant 20,21-25,26-30$, $31-35$ and $\geqslant 36$ years. Serum results were classified as positive or negative. In the univariate analysis, the frequency for each of the age categories and the mean, median and maximum and minimum age for the overall sample were determined, as well as SD. We repeated the univariate analysis of age after having stratified the data by serum analysis results and compared the mean ages for a statistically significant difference using Student's $t$-test. We also obtained the frequency of seropositive and seronegative women. In the bivariate analysis, we evaluated the relationship between age and serum results categories using Pearson's $\chi^{2}$ test. Logistic regression analysis was used to model the relationship between age categories and serum results. The logistic model with a maximum-likelihood estimate was fitted to the ordinal response of age categories and $95 \%$ confidence intervals for the odd ratios were calculated with the age category of $\leqslant 20$ years as the reference group. A $\chi^{2}$ test for trend over increasing age categories was also performed.

\section{RESULTS}

A total of 960 pregnant women was screened for HTLV-I antibodies. Their ages ranged from 15 to 41 years, with a mean age \pm SD of $25 \cdot 6 \pm 5 \cdot 8$ years. The median and modal ages of all of the pregnant women studied were 26 years. All of the patients were found to be healthy on routine antenatal medical examination. In the primary screening, $24(2 \cdot 5 \%)$ samples tested positive by gelatin PAT. All of the samples were assayed in duplicate and repeatedly positive samples were confirmed by WB analysis. WB results indicated that, of these 24 repeatedly PAT-positive specimens, 20 specimens $(83 \cdot 3 \%)$ were HTLV-I positive, one $(4 \cdot 2 \%)$ was HTLV-II positive, two $(8 \cdot 3 \%)$ were HTLV positive and one $(4 \cdot 2 \%)$ was indeterminate. In order to address the issue of false negatives during the PAT screening, 24 repeatedly PATnegative specimens were randomly selected and analysed by 
WB. All of these 24 PAT-negative specimens were found to be HTLV negative by WB (no reactivity to HTLV-specific bands).

Therefore, the overall HTLV-I seroprevalence rate among pregnant women in Accra over the 12 month period was $2 \cdot 1 \%$. The age distribution of pregnant women seropositive for HTLV-I ranged from 18 to 38 years and their median and modal ages were 35 and 37 years, respectively. The age distribution of pregnant women seronegative for HTLV-I ranged from 15 to 41 years and both their median and modal ages were 26 years. The mean age $( \pm S D)$ of the seropositive pregnant women $(32 \cdot 4 \pm 6 \cdot 0$ years) was significantly higher $(P<0.0001)$ than that of the mean age of the seronegative pregnant women $(25 \cdot 6 \pm 5 \cdot 8$ years $)$. A highly significant correlation existed between increasing age and HTLV-I seropositivity $(P<0 \cdot 0001$; Table 1$)$.

\section{DISCUSSION}

The HTLV-I seroprevalence of $2 \cdot 1 \%$ in Ghanaian pregnant women reported here agrees well with what is known about the endemicity of HTLV-I in West Africa and among ethnic groups of African origin (Kazanji \& Gessain, 2003; Carles et al., 2004). For example, in French Guyana, the overall seroprevalence in pregnant women is $4 \cdot 4 \%$, but it is more prevalent among ethnic groups of African origin, such as the Noir Marron population $(5 \cdot 5 \%)$ and Haitians $(6 \cdot 3 \%)$ (Carles et al., 2004). Our observed rapid increase in seroprevalence with age and the low seroprevalence in the youngest age groups (Table 1) point to sexual contact as the primary mode of transmission among women of childbearing age, with only a small fraction attributable to breastfeeding during infancy. This is also consistent with reports from other endemic countries (Murphy et al., 1991; Kazanji \& Gessain, 2003). Indeed, this suggests the importance of man-to-woman transmission in these pregnant women, as the duration of their sexual activity increases with age, whilst mother-to-child transmission would be the predominant route in the younger women/girls through breastfeeding during infancy. This is supported further by our observation that the mean age of the seropositive pregnant women was

Table 1. Odds ratios for HTLV-I seropositivity and corresponding $95 \%$ confidence intervals $(\mathrm{Cl})$ by age of pregnant women in Accra, Ghana

$\chi^{2}$ test for trend (d.f. $=1$ ): $\chi^{2}=30 \cdot 36 ; P<0 \cdot 0001$.

\begin{tabular}{|lcccc|}
\hline $\begin{array}{l}\text { Age } \\
(\text { years })\end{array}$ & $\begin{array}{c}\text { Women } \\
(\boldsymbol{n})\end{array}$ & $\begin{array}{c}\text { HTLV-I-positive } \\
\text { women [ } \boldsymbol{n}(\%)]\end{array}$ & $\begin{array}{c}\text { Odds } \\
\text { ratio }\end{array}$ & $\begin{array}{c}\mathbf{9 5} \% \\
\text { CI }\end{array}$ \\
\hline$\leqslant 20$ & 220 & $1(0 \cdot 45)$ & 1 & - \\
$21-25$ & 251 & $2(0 \cdot 80)$ & $1 \cdot 76$ & $0 \cdot 16-19 \cdot 53$ \\
$26-30$ & 311 & $3(0 \cdot 96)$ & $2 \cdot 13$ & $0 \cdot 22-20 \cdot 64$ \\
$31-35$ & 113 & $5(4 \cdot 42)$ & $10 \cdot 14$ & $1 \cdot 17-87 \cdot 83$ \\
$\geqslant 36$ & 65 & $9(13 \cdot 85)$ & $35 \cdot 19$ & $4 \cdot 37-283 \cdot 53$ \\
\hline
\end{tabular}

significantly higher $(P<0 \cdot 0001)$ than that of the seronegative women.

The HTLV-I seroprevalence of $2 \cdot 1 \%$ among the healthy Ghanaian pregnant women in the current study was somewhat lower than the seroprevalence of $4 \cdot 2 \%$ reported recently in healthy Ghanaian blood donors (Adjei et al., 2003a). This difference is probably due to the fact that most blood donors in Ghana are replacement donors (usually relatives of hospitalized patients who need transfusion) rather than non-compensated repeat voluntary donors and to the reported significantly higher prevalence of viral markers of HIV-1/2, hepatitis B virus, hepatitis C virus and HTLV-I/ II in replacement blood donors compared with voluntary blood donors in Ghana (Sarkodie et al., 2001). In sharp contrast, the mean seroprevalence of HTLV-I in Western Europe was sixfold higher among pregnant women than among blood donors, probably because the vast majority of blood donors in Western Europe are non-compensated repeat voluntary donors rather than replacement donors (Taylor et al., 2005).

The epidemiology of sexually transmitted diseases (including HTLV and HIV) in pregnant women is often used to approximate the epidemiology within the general population, as pregnant women are generally considered to be the most sexually active segment of the population. Therefore, excess sera from blood samples drawn from pregnant women for their routine antenatal testing are used for sentinel surveillance of HIV in Ghana (Ministry of Health, 2004) and in several other countries. The HTLV-I seroprevalence of $2 \cdot 1 \%$ among Ghanaian pregnant women reported here is comparable to the $3 \cdot 1 \%$ seroprevalence of HIV- 1 and -2 among pregnant women in Ghana (Ministry of Health, 2004). A comparison of our results with similar studies around the world (Table 2) confirms the known endemicity of HTLV-I in Japan, sub-Saharan Africa, the Caribbean Basin and parts of South America, but not in Western Europe (Kazanji \& Gessain, 2003).

The policy of not screening for HTLV antibody in pregnant women and in blood and organ donors in most countries is based partly on its perceived low prevalence and on the low lifetime risk of its associated diseases, although the cost of antenatal and blood-donor screening could be limited by selecting those thought to be at high risk. With appropriate counselling, screening for HTLV should be accepted in the same light as testing for HIV, which recently has been recommended as part of the routine antenatal screening programme in several countries (Nightingale et al., 1993; Hanchard, 1996; Weber \& Taylor, 1996; Hale et al., 1997; Otigbah et al., 1997; Taylor et al., 2005; Wiktor et al., 1997). However, unlike HIV infection, infection with HTLV is less likely to become clinically apparent and the factors that confer a high risk of developing associated disease have not been defined. In the meantime, antenatal screening and the promotion of bottle-feeding for children of seropositive mothers could help limit vertical transmission, as its costeffectiveness has been proven in Japan (Kashiwagi et al., 
Table 2. Comparison of HTLV-I seroprevalence in pregnant women worldwide

\begin{tabular}{|c|c|c|}
\hline Country & $\begin{array}{c}\text { Seroprevalence } \\
(\%)\end{array}$ & Reference(s) \\
\hline \multicolumn{3}{|l|}{ Sub-Saharan Africa } \\
\hline Ghana & $2 \cdot 1$ & This study \\
\hline The Gambia & $1 \cdot 2$ & Del Mistro et al. (1994) \\
\hline Guinea-Bissau & $2 \cdot 3$ & Andersson et al. (1997) \\
\hline Mozambique & $0 \cdot 7$ & Melo et al. (2000) \\
\hline Congo & $0 \cdot 7$ & Tuppin et al. (1996) \\
\hline Gabon & $6 \cdot 8-10 \cdot 5$ & $\begin{array}{l}\text { Delaporte et al. (1988); } \\
\text { Schrijvers et al. (1991) }\end{array}$ \\
\hline Zaire & $2 \cdot 4-14 \cdot 8$ & $\begin{array}{l}\text { Goubau et al. (1993); } \\
\text { Delaporte et al. (1995) }\end{array}$ \\
\hline \multicolumn{3}{|l|}{ South America } \\
\hline Brazil & $0 \cdot 84-0 \cdot 88$ & $\begin{array}{l}\text { dos Santos et al. (1995); } \\
\text { Bittencourt et al. (2001) }\end{array}$ \\
\hline Peru & $2 \cdot 3-2 \cdot 5$ & $\begin{array}{l}\text { Zurita et al. (1997); } \\
\text { Sanchez-Palacios et al. } \\
\text { (2003) }\end{array}$ \\
\hline \multicolumn{3}{|l|}{ Caribbean Basin } \\
\hline $\begin{array}{l}\text { Martinique (French } \\
\text { West Indies) }\end{array}$ & $1 \cdot 93$ & Mansuy et al. (1999) \\
\hline Jamaica & $2 \cdot 0$ & Dowe et al. (1998) \\
\hline French Guyana & $4 \cdot 4$ & Carles et al. (2004) \\
\hline \multicolumn{3}{|l|}{ Asia Pacific } \\
\hline Japan & $3 \cdot 7$ & Kashiwagi et al. (2004) \\
\hline \multicolumn{3}{|l|}{ Western Europe } \\
\hline Germany & $0 \cdot 007$ & Taylor et al. (2005) \\
\hline Spain & $0 \cdot 010$ & Taylor et al. (2005) \\
\hline Portugal & $0 \cdot 013$ & Taylor et al. (2005) \\
\hline Italy & $0 \cdot 017$ & Taylor et al. (2005) \\
\hline Belgium & $0 \cdot 020$ & Taylor et al. (2005) \\
\hline UK & $0 \cdot 047$ & Taylor et al. (2005) \\
\hline France & $0 \cdot 115$ & Taylor et al. (2005) \\
\hline
\end{tabular}

2004). Therefore, it has been recommended that HTLV-I should be screened for during pregnancy in women living in and originating from highly HTLV-I-endemic countries; in cases of HTLV-I seropositivity, mothers should be informed of the risks of transmission and the promotion of bottlefeeding of their children should be strongly proposed (Carles et al., 2004). Additionally, determination of the HTLV-I serostatus of pregnant women would ensure that doctors could take further precautions to protect against nosocomial infection and to ensure that newborns do not swallow blood at the time of delivery from HTLV-I-seropositive mothers, in order to minimize perinatal HTLV-I transmission in nonbreastfed children of HTLV-I-seropositive mothers (Carles et al., 2004).

The argument for antenatal HTLV testing in Ghana is compelling, as breastfeeding is prolonged and widespread among Ghanaian women. Our findings re-emphasize the suggestion that targeting high-risk women or universal testing in high-prevalence areas, which includes Ghana, could identify most women infected with HTLV at a relatively low cost (Ades et al., 2000). Antenatal HTLV testing is likely to be less beneficial economically and clinically than antenatal HIV testing, but should be evaluated fully, as the risks of infection and disease after contaminated transfusion are less with HTLV than with HIV (Ades et al., 2000). This study highlights the need for screening of pregnant women for circulating antibodies to HTLV-I. A further larger-scale prospective survey of HTLV-I infection in Ghana should be conducted to verify the results of the present study and to analyse in more detail the epidemiological features of this retroviral infection and evaluate the cost-effectiveness of antenatal HTLV screening in Ghana.

In conclusion, the results of this study and our recent results in healthy blood donors (Adjei et al., 2003a) demonstrate a high prevalence of HTLV-I infection in Ghana. Therefore, preventative measures to decrease the spread and transmission of HTLV in Ghana are warranted. These measures should include the systematic HTLV-I screening of blood donors and pregnant women in order to counsel them about the risk of HTLV-I transmission by prolonged breastfeeding, and the prevention of sexual transmission of HTLV-I by educational programmes emphasizing the importance of using condoms to prevent all sexually transmitted diseases, including HIV and HTLV infection.

\section{ACKNOWLEDGEMENTS}

This work was funded by a research grant from the Korle-Bu Teaching Hospital, Korle-Bu, Accra, Ghana.

\section{REFERENCES}

Ades, A. E., Parker, S., Walker, J., Edginton, M., Taylor, G. P. \& Weber, J. N. (2000). Human $T$ cell leukaemia/lymphoma virus infection in pregnant women in the United Kingdom: population study. BMJ 320, 1497-1501.

Adjei, A. A., Adiku, T. K., Ayeh-Kumi, P. F., Armah, H., Ansah, J. \& Hesse, I. F. A. (2003a). Prevalence of antibodies to human T-lymphotropic virus type I among blood doors in Accra, Ghana. Ghana Medical J 37, 133-136.

Adjei, A. A., Adiku, T. K., Ayeh-Kumi, P. F. \& Domfeh, A. B. (2003b). Human T-lymphotropic type-I virus specific antibody detected in sera of HIV/AIDS patients in Ghana. Jpn J Infect Dis 56, 57-59.

Ampofo, W., Nii-Trebi, N., Ansah, J. \& 8 other authors (2002). Prevalence of blood-borne infectious diseases in blood donors in Ghana. J Clin Microbiol 40, 3523-3525.

Andersson, S., Dias, F., Mendez, P. J., Rodrigues, A. \& Biberfeld, G. (1997). HTLV-I and HTLV-II infections in a nationwide survey of pregnant women in Guinea-Bissau, West Africa. J Acquir Immune Defic Syndr 15, 320-322.

Bittencourt, A. L., Dourado, I., Filho, P. B., Santos, M., Valadão, E., Alcantara, L. C. J. \& Galvão-Castro, B. (2001). Human T-cell lymphotropic virus type 1 infection among pregnant women in northeastern Brazil. J Acquir Immune Defic Syndr 26, 490-494.

Blattner, W. A., Saxinger, C., Riedel, D., Hull, B., Taylor, G., Cleghorn, F., Gallo, R., Blumberg, B. \& Bartholomew, C. (1990). A 
study of HTLV-I and its associated risk factors in Trinidad and Tobago. J Acquir Immune Defic Syndr 3, 1102-1108.

Carles, G., Tortevoye, P., Tuppin, P., Ureta-Vidal, A., Peneau, C., El Guindi, W. \& Gessain, A. (2004). HTLV-1 infection and pregnancy. J Gynecol Obstet Biol Reprod 33, 14-20 (in French).

Cleghorn, F. R., Manns, A., Falk, R. \& 7 other authors (1995). Effect of human T-lymphotropic virus type I infection on non-Hodgkin's lymphoma incidence. J Natl Cancer Inst 87, 1009-1014.

Delaporte, E., Dupont, A., Peeters, M. \& 9 other authors (1988). Epidemiology of HTLV-I in Gabon (Western Equatorial Africa). Int $J$ Cancer 42, 687-689.

Delaporte, E., Buve, A., Nzila, N. \& 7 other authors (1995). HTLV-I infection among prostitutes and pregnant women in Kinshasa, Zaire: how important is high-risk sexual behavior? J Acquir Immune Defic Syndr Hum Retroviruses 8, 511-515.

Del Mistro, A., Chotard, J., Hall, A. J., Fortuin, M., Whittle, H., de Rossi, A. \& Chieco-Bianchi, L. (1994). HTLV-I/II seroprevalence in The Gambia: a study of mother-child pairs. AIDS Res Hum Retroviruses 10, 617-620.

dos Santos, J. I., Lopes, M. A., Deliege-Vasconcelos, E., CoutoFernandez, J. C., Patel, B. N., Barreto, M. L., Ferreira Junior, O. C. \& Galvao-Castro, B. (1995). Seroprevalence of HIV, HTLV-I/II and other perinatally transmitted pathogens in Salvador, Bahia. Rev Inst Med Trop Sao Paulo 37, 343-348.

Dowe, G., King, S. D., Smikle, M. F., Wynter, H. H., Chout, R. \& Klaskala, W. (1998). Prevalence of viral and bacterial sexually transmitted pathogens in Jamaican pregnant women. West Indian Med J 47, 23-25.

Gessain, A., Barin, F., Vernant, J. C., Gout, O., Maurs, L., Calender, A. \& de Thé, G. (1985). Antibodies to human T-lymphotropic virus type-I in patients with tropical spastic paraparesis. Lancet ii, 407-410.

Goubau, P., Desmyter, J., Swanson, P., Reynders, M., Shih, J., Surmont, I., Kazadi, K. \& Lee, H. (1993). Detection of HTLV-I and HTLV-II infection in Africans using type-specific envelope peptides. J Med Virol 39, 28-32.

Hale, A., Leung, T., Sivasubramanian, S., Kenny, J. \& Sutherland, S. (1997). Prevalence of antibodies to HTLV in antenatal clinic attenders in south east London. J Med Virol 52, 326-329.

Hanchard, B. (1996). Adult T-cell leukemia/lymphoma in Jamaica: 1986-1995. J Acquir Immune Defic Syndr 13, S20-S25.

Hino, S., Katamine, S., Miyata, H., Tsuji, Y., Yamabe, T. \& Miyamoto, T. (1996). Primary prevention of HTLV-I in Japan. J Acquir Immune Defic Syndr 13, S199-S203.

Hirata, M., Hayashi, J., Noguchi, A., Nakashima, K., Kajiyama, W., Kashiwagi, S. \& Sawada, T. (1992). The effects of breastfeeding and presence of antibody to $\mathrm{p} 40^{\text {tax }}$ protein of human $\mathrm{T}$ cell lymphotropic virus type-I on mother to child transmission. Int J Epidemiol 21, 989-994.

Inaba, S., Okochi, K., Sato, H., Fukada, K., Kinukawa, N., Nakata, H., Kinjyo, K., Fujii, F. \& Maeda, Y. (1999). Efficacy of donor screening for HTLV-I and the natural history of transfusion-transmitted infection. Transfusion 39, 1104-1110.

Kajiyama, W., Kashiwagi, S., Ikematsu, H., Hayashi, J., Nomura, H. \& Okochi, K. (1986). Intrafamilial transmission of adult $\mathrm{T}$ cell leukemia virus. J Infect Dis 154, 851-857.

Kashiwagi, K., Furusyo, N., Nakashima, H., Kubo, N., Kinukawa, N., Kashiwagi, S. \& Hayashi, J. (2004). A decrease in mother-to-child transmission of human T lymphotropic virus type I (HTLV-I) in Okinawa, Japan. Am J Trop Med Hyg 70, 158-163.

Kazanji, M. \& Gessain, A. (2003). Human T-cell lymphotropic virus types I and II (HTLV-I/II) in French Guiana: clinical and molecular epidemiology. Cad Saude Publica Rio de Janeiro 19, 1227-1240.
Kishihara, Y., Furusyo, N., Kashiwagi, K., Mitsutake, A., Kashiwagi, S. \& Hayashi, J. (2001). Human T lymphotropic virus type 1 infection influences hepatitis $\mathrm{C}$ virus clearance. J Infect Dis 184, 1114-1119.

Lal, R. B., Owen, S. M., Mingle, J., Levine, P. H. \& Manns, A. (1994). Presence of human T-lymphotropic virus types I and II in Ghana, West Africa. AIDS Res Hum Retroviruses 10, 1747-1750.

Manns, A., Wilks, R. J., Murphy, E. L., Haynes, G., Figueroa, J. P., Barnett, M., Hanchard, B. \& Blattner, W. A. (1992). A prospective study of transmission by transfusion of HTLV-I and risk factors associated with seroconversion. Int J Cancer 51, 886-891.

Mansuy, J. M., Schlegel, L., Villeneuve, L., Mengelle, C. \& Magnaval, J. F. (1999). Seroprevalence of retroviral infections among pregnant women in Martinique (French West Indies). Am J Trop Med Hyg 61, 598-599.

Melo, J., Beby-Defaux, A., Faria, C., Guiraud, G., Folgosa, E., Barreto, A. \& Agius, G. (2000). HIV and HTLV prevalences among women seen for sexually transmitted diseases or pregnancy follow-up in Maputo, Mozambique. J Acquir Immune Defic Syndr 23, 203-204.

Ministry of Health (1990). Policy Guidelines and Annual Report. Accra, Ghana: Maternal \& Child Health Unit, Ghana Health Service.

Ministry of Health (2004). HIV Sentinel Survey. 2004 Report. Accra, Ghana: National AIDS/STI Control Programme, Ghana Health Service. http://www.who.int/countries/gha/publications/Sentinel_Report_ 2004.pdf

Murphy, E. L., Figueroa, J. P., Gibbs, W. N., Holding-Cobham, M., Cranston, B., Malley, K., Bodner, A. J., Alexander, S. S. \& Blattner, W. A. (1991). Human T-lymphotropic virus type I (HTLV-I) seroprevalence in Jamaica. I. Demographic determinants. Am J Epidemiol 133, 1114-1124.

Nightingale, S., Orton, D., Ratcliffe, D., Skidmore, S., Tosseill, J. \& Desselberger, U. (1993). Antenatal survey for the seroprevalence of HTLV-I infections in the West Midlands, England. Epidemiol Infect 110, 379-387.

Okochi, K., Sato, H. \& Hinuma, Y. (1984). A retrospective study on transmission of adult $\mathrm{T}$ cell leukemia virus by blood transfusion: seroconversion in recipients. Vox Sang 46, 245-253.

Osame, M., Matsumoto, M., Usuku, K., Izumo, S., Ijichi, N., Amitani, H., Tara, M. \& Igata, A. (1987). Chronic progressive myelopathy associated with elevated antibodies to human T-lymphotropic virus type I and adult T-cell leukemialike cells. Ann Neurol 2, 117-122.

Otigbah, C., Kelly, A., Aitken, C., Norman, J., Jeffries, D. \& Erskine, K. J. (1997). Is HTLV-I status another antenatal screening test that we need? Br J Obstet Gynaecol 104, 258-260.

Poiesz, B. J., Ruscetti, F. W., Gazdar, A. F., Bunn, P. A., Minna, J. D. \& Gallo, R. C. (1980). Detection and isolation of type C retrovirus particles from fresh and cultured lymphocytes of a patient with cutaneous T-cell lymphoma. Proc Natl Acad Sci U S A 77, 7415-7419.

Sanchez-Palacios, C., Gotuzzo, E., Vandamme, A. M. \& Maldonado, Y. (2003). Seroprevalence and risk factors for human T-cell lymphotropic virus (HTLV-I) infection among ethnically and geographically diverse Peruvian women. Int J Infect Dis 7, 132-137.

Sarkodie, F., Adarkwa, M., Adu-Sarkodie, Y., Candotti, D., Acheampong, J. W. \& Allain, J. P. (2001). Screening for viral markers in volunteer and replacement blood donors in West Africa. Vox Sang 80, 142-147.

Schrijvers, D., Delaporte, E., Peeters, M., Dupont, A. \& Meheus, A. (1991). Seroprevalence of retroviral infection in women with different fertility statuses in Gabon, western equatorial Africa. J Acquir Immune Defic Syndr 4, 468-470. 
Takatsuki, K., Matsuoka, M. \& Yamaguchi, K. (1996). Adult T-cell leukemia in Japan. J Acquir Immune Defic Syndr Hum Retrovirol 13, S15-S19.

Takezaki, T., Tajima, K., Ito, M., Ito, S., Kinoshita, K., Tachibana, K. \& Matsushita, Y. (1997). Short-term breast-feeding may reduce the risk of vertical transmission of HTLV-I. The Tsushima ATL Study Group. Leukemia 11 (Suppl. 3), 60-62.

Taylor, G. P., Bodéus, M., Courtois, F. \& 11 other authors (2005). The seroepidemiology of human T-lymphotropic viruses types I and II in Europe: a prospective study of pregnant women. J Acquir Immune Defic Syndr 38, 104-109.

Tsuji, Y., Doi, H., Yamabe, T., Ishimaru, T., Miyamoto, T. \& Hino, S. (1990). Prevention of mother-to-child transmission of human T-lymphotropic virus type-I. Pediatrics 86, 11-17.

Tuppin, P., Makuwa, M., Guerma, T., Bazabana, M. M., Loukaka, J. C., Jeannel, D. M'Pele P. \& de Thé, G. (1996). Low HTLV-I/II seroprevalence in pregnant women in Congo and a geographic cluster of an HTLV-like indeterminate Western blot pattern. J Acquir Immune Defic Syndr Hum Retrovirol 11, 105-107.

Weber, J. N. \& Taylor, G. P. (1996). Antenatal screening is important. $B M J$ 312, 706.

Wiktor, S. Z., Pate, E. J., Rosenberg, P. S., Barnett, M., Palmer, B., Medeiros, D., Maloney, E. M. \& Blattner, W. A. (1997). Motherto-child transmission of human T-cell lymphotropic virus type I associated with prolonged breast-feeding. J Hum Virol 1, 37-44.

Yoshida, M., Miyoshi, I. \& Hinuma, Y. (1982). Isolation and characterization of retrovirus from cell lines of human adult T-cell leukemia and its implication in the disease. Proc Natl Acad Sci U S A 79, 2031-2035.

Zurita, S., Costa, C., Watts, D., Indacochea, S., Campos, P., Sanchez, J. \& Gotuzza, E. (1997). Prevalence of human retroviral infection in Quillabamba and Cuzco, Peru: a new endemic area for human T cell lymphotropic virus type 1. Am J Trop Med Hyg 56, 561-565. 